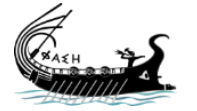

journal.phaselis.org
PHAS LLIS Issue V (2019)
Disiplinlerarası Akdeniz Araştırmaları Dergisi

Journal of Interdisciplinary Mediterranean Studies

\title{
Akhisar, Karahöyük Dağı ve Çevresinde Tespit Edilen Höyük ve Yamaç Yerleşimleri
}

\author{
Mound and Hillside Settlements Located in Karahöyük Mount \\ (Akhisar) and its Territory
}

\author{
Aydın ERÖN \\ (D) https://orcid.org/0000-0003-1611-2296
}

open 2 access journals

The entire contents of this journal, Phaselis: Journal of Interdisciplinary Mediterranean Studies, is open to users and it is an 'open access' journal. Users are able to read the full texts, to download, to copy, print and distribute without obtaining the permission of the editor and author(s). However, all references to the articles published in the e-journal Phaselis are to indicate through reference the source of the citation from this journal.

Phaselis: Journal of Interdisciplinary Mediterranean Studies is a peer-reviewed journal and the articles which have had their peer reviewing process completed will be published on the web-site (journal.phaselis.org) in the year of the journal's issue (e.g. Issue IV: JanuaryDecember 2018). At the end of December 2018 the year's issue is completed and Issue V: January-December 2019 will begin.

Responsibility for the articles published in this journal remains with the authors.

cc) (i) (2) This work is licensed under a Creative Commons AttributionNonCommercial-ShareAlike 4.0 International License.

Citation A. Erön, "Akhisar, Karahöyük Dağı ve Çevresinde Tespit Edilen Höyük ve Yamaç Yerleşimleri". Phaselis V (2019) 397-411. http://dx.doi.org/10.18367/Pha.19027

Received Date: 12.11.2019 | Acceptance Date: 19.11.2019

Online Publication Date: 29.12.2019

Editing Phaselis Research Project

www.phaselis.org 


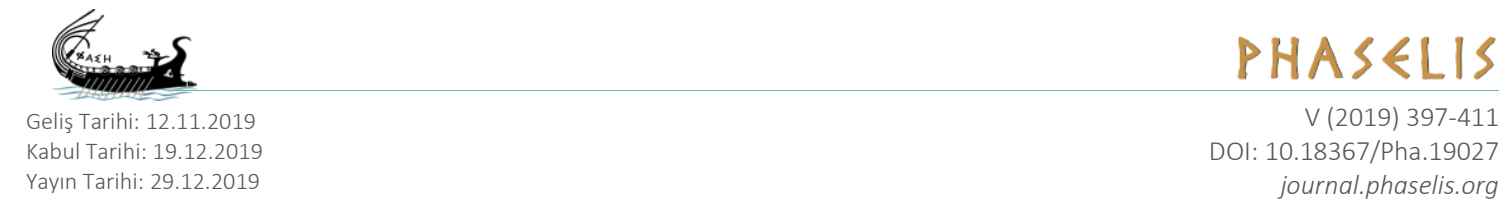

\title{
Akhisar, Karahöyük Dağı ve Çevresinde Tespit Edilen Höyük ve Yamaç Yerleşimleri
}

\author{
Mound and Hillside Settlements Located in Karahöyük Mount (Akhisar) \\ and its Territory
}

\begin{abstract}
Aydın ERÖN *
Öz: Karahöyük Dağı Manisa ili, Akhisar ilçe sınırları içerisinde yer almaktadır. Bereketli Akhisar Ovasının ortasında yer alan dağın çevresi erken dönemlerden başlayarak günümüze kadar iskan için tercih edilmiştir. Karahöyük Dağı ve çevresindeki arkeolojik kalıntı ve buluntuların tespit edilmesi amacıyla ekibimiz tarafından söz konusu alanda 2016-2018 yılları arasında bir yüzey araştırması çalışması gerçekleştirilmiştir. Söz konusu çalışmalar sırasında 9 adet höyük ve yamaç yerleşimi tespit edilmiştir. İncelenen höyüklerden dört tanesi daha önceden tespit edilmiş yerleşimlerdir. Çamaltı I, Çamaltı II, Kocanadas ve Koca Zeytin Tepe mevkilerinde yer alan yerleşimler ise ilk kez ekibimiz tarafından bulunmuştur. Araştırma sahası içerisinde kalan yerleşimlerin altı tanesi höyük, üç tanesi ise yamaç yerleşimi niteliğindedir. Yapılan değerlendirmeler sonucunda dağın en çok güney bölümünün iskan için tercih edildiği anlaşılmışıı. Seramik buluntuları yerleşimlerin iskan gördükleri dönemlerin tespitinde oldukça önemlidir. Yapılan incelemeler sonucunda Moralılar Höyüğü ve Kocanadas mevkiinde yer alan höyükte Geç Neolitik-Erken Kalkolitik Çağ seramik buluntuları ile karşılamıştır. Seramikler Karahöyük Dağı çevresinde iskanın Geç Neolitik Çağda başladığını kanıtlamaktadır. Çalışma sahası içerisinde yer alan höyük ve yamaç yerleşimlerinin birçoğunda iskan Osmanlı Dönemine kadar devam etmiştir. Dönemsel olarak incelendiğinde höyük ve yamaç yerleşimlerinde Geç Demir Çağına (MÖ 5-4. yüzyıl) tarihlendirilen herhangi seramik parçası tespit edilememiştir. Bu durum Pers egemenliğinin baskıcı tutumu ile bağlantılı olmalıdır. Yapılan incelemeler sonuncunda Kocanadas Mevkiinde yer alan höyüğün GDÇ hariç bütün dönemlerde iskan gördüğü anlaşılmıştır.
\end{abstract}

Anahtar sözcükler: Akhisar, Karahöyük Dağı, Höyük, Yamaç Yerleşimi, İskan

Abstract: Karahöyük Mount is located in Akhisar district of Manisa province. Starting from the early periods up to the present day, the surrounding area of the mountain, which is located in the middle of fertile Akhisar Plain, has been preferred for resettlement. Our team conducted a survey between 2016 and 2018 in order to identify the archaeological remains and finds on the Karahöyük Mount and the surrounding area. 9 mounds and hillside settlements were identified during these studies. Four of these places are the previously identified settlements. The settlements in Çamaltı I, Çamaltı II, Kocanadas and Koca Zeytin Tepe locations were first discovered by our team. 6 of the settlements within the research area are mounds and 3 of them are hillside settlements. As a result of the evaluations, it was understood that the southern part of the mountain was preferred as a settlement. Potteries are very important in dating the periods when the settlements were inhabited. As a result of the investigations we conducted, the potteries recovered from the Moralılar Mound and Kocanadas Mound are dated to the Late Neolithic-Early Chalcolithic Age. The potteries prove that the settlement around the Karahöyük Mount started in the Late Neolithic Age. Most of the mound and hillside settlements in our study area were inhabited until the Ottoman period. No fragments of pottery dating to the Late Iron Age $\left(\mathrm{V}-\mathrm{IV}^{\text {th }}\right.$ century $\left.\mathrm{BC}\right)$ were identified in the mound and hillside settlements. The repressive attitude of Persian sovereignty should be the reason for this situation. As a result of the investigations, it was found that the mound in Kocanadas Mevkii was inhabited in all periods except the Late Iron Age.

Keywords: Akhisar, Karahoyuk Mount, Mound, Hillside Settlement, Settlement

* Dr. Öğr. Üyesi, Aydın Adnan Menderes Üniversitesi, Fen-Edebiyat Fakültesi, Arkeoloji Bölümü, 09100 Aytepe-Aydın. aeron@adu.edu.tr | io https://orcid.org/0000-0003-1611-2296 
Giriş

Karahöyük Dağı Manisa ili, Akhisar ilçe sınırları içerisinde yer almaktadır (Fig. 1). Oldukça stratejik bir noktada yer alan dağın kuzeyinden Balıkesir-Manisa yolu, doğusundan ise AkhisarSalihli yolu geçmektedir. Akhisar ilçe merkezine kuş uçuşu $4 \mathrm{~km}$ uzaklıktadır. $525 \mathrm{~m}$ yüksekliğindeki dağın güneyinde Moralılar ve Rahmiye mahalleleri yer almaktadır. Dağın batısında ise Kayalığlu Mahallesi bulunur. Karahöyük Dağı ve çevresindeki arkeolojik kalıntı ve buluntuların tespit edilmesi amacıyla ekibimiz tarafından söz konusu alanda 2016 yılında bir yüzey araştırması çalışması başlatılmıştır (Fig. 2).

2016-2018 yılları arasında gerçekleştirilen yüzey araştırması çalışmalarının ana amaçlarından bir tanesini Karahöyük Dağı çevresinde yer alan höyük ve yerleşimlerin tespit edilmesi oluşturmaktadır. İnsanoğlunun yaşayacağı yeri belirlerken ihtiyaçlarını ve beğenilerini dikkate aldığı bilinmektedir. Akhisar Ovasında yerleşik düzene geçişin başladığı Geç Neolitik Çağ’dan başlayarak iskan gördüğü anlaşılan höyük ve yerleşimlerin yer seçiminde de ihtiyaç ve beğeniler önemli bir yer tutmuş olmalıdır.

Karahöyük Dağı ve çevresinde 2016-2018 yılları arasında gerçekleştirilen yüzey araştırması çalışmaları sırasında toplam 9 tane höyük ve yamaç yerleşimi tespit edilmiştir (Fig. 3). 2016 yılı çalışmaları sırasında Karahöyük Dağının doğu ve güney yönünde yer alan arkeolojik kalıntı ve buluntuların tespit edilmesine ağırlık verilmiştir ${ }^{1}$. Arazinin doğu bölümünde yer alan Çamaltı I, Çamaltı II mevkilerinde yer alan yamaç yerleşimleri ile güneyinde yer alan Moralılar, Örentepe ve Rahmiye II höyükleri ilk yılki çalışmalar sırasında incelenmiştir.

2017 yılı çalışmaları ağılıklı olarak Karahöyük Dağı'nın kuzey ve batısında gerçekleştirilmiştir². Söz konusu çalışmalar sırasında Karahöyük Dağı'nın doğusunda yer alan fakat 2016 yılı çalışmaları sırasında tarım arazisi olarak kullanıldığı için incelemeyen Akhisar Höyük alanı da incelenmiştir. Ayrıca çalışma sahasının kuzeydoğusuna doğru yer alan Çamaltı III mevkii ve Balıkesir-Manisa yolunun güneybatısında ${ }^{3}$ kalan alanlarda da incelemelerde bulunulmuştur. 2017 yılı çalışmaları sırasında Karahöyük Dağı'nın güneybatısında yer alan Kocanadas Mevkii'nde yer alan arazi de ayrıntılı bir şekilde incelenmiştir.

2018 yılı çalışmaları ağırııkı olarak Karahöyük Dağı'nın zirvesinde gerçekleştirilmiştir. 2016 ve 2017 araştırmaları sırasında tespit edilen höyük alanlarından bazılarına tekrar gidilerek yeni kalıntı ve buluntular tespit edilmeye çalışılmışı ı ${ }^{4}$ Kocanadas Mevkii, Rahmiye II ve Moralılar höyükleri 2018 yılı çalışmaları sırasında tekrar incelenmiştir. Çalışma sahasının batıında, olasılıkla bir yamaç yerleşimi olan arazide incelemelerde bulunulmuştur. Söz konusu mevkii yöre halkı tarafından Küçük Zeytin Tepe olarak adlandırılmaktadır.

Karahöyük Dağı ve çevresinde gerçekleştirilen yüzey araştırması çalışmaları sırasında incelenen höyük ve yamaç yerleşimlerinden dört tanesinin (Çamaltı I, Çamaltı II, Kocanadas ve Küçük Zeytin Tepe) ilk kez ekibimiz tarafından tespit edilmiştir. Bu açıdan oldukça önemlidir. Diğer beş höyük ise bölgede geçmiş yıllarda araştırmalar gerçekleştirilen bilim insanları tarafından tespit edilmiştir.

Erön et al. 2018, 147-153.

2 Erön et al. 2019, 237-242. 2017 yılı çalışmaları sırasında ilk olarak 2016 yılında incelenen araştırma alanlarına tekrar gidilmiş, bir tahribat olup olmadığı tespit edilmeye çalışılmıştır.

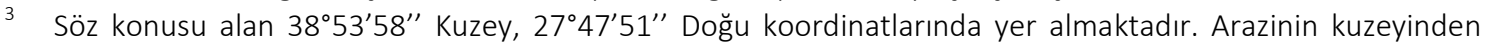
Balıkesir-Manisa yolu geçmektedir. Yolun kuzeyinde çalışma sahamız dışında yer alan Dağdeviren Höyüğü bulunmaktadır. Yüzey araştırması çalışmaları sırasında bulunan seramik örneklerinin Dağdeviren Höyüğü ile bağlantılı olma ihtimali oldukça yüksektir.

4 Karahöyük Dağı'nın doğu, batı ve özellikle güney etekleri tarım arazisi olarak kullanılmaktadır. Tarlaların sürülme zamanlarında yüzeyde yeni buluntu ve kalıntılarla karşılaşılma olasıllığı oldukça yüksek olduğu için araştırma sahası içerisinde kalan höyükler daha sonradan tekrar ziyaret edilmektedir. 


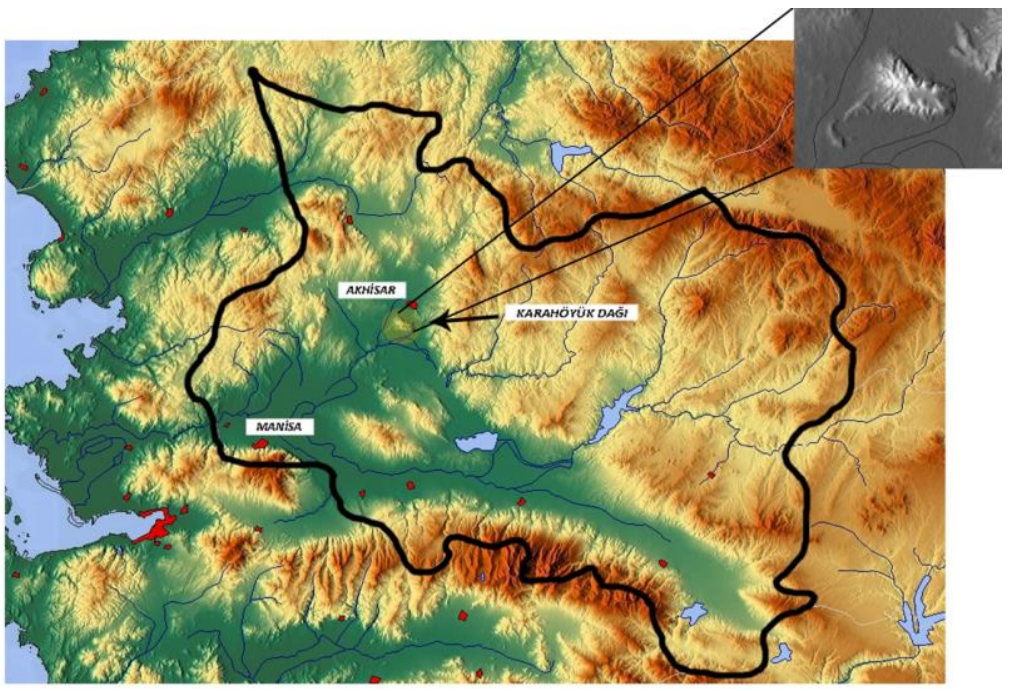

Fig. 1. Karahöyük Dağı'nın Yerini Gösteren Topografik Harita

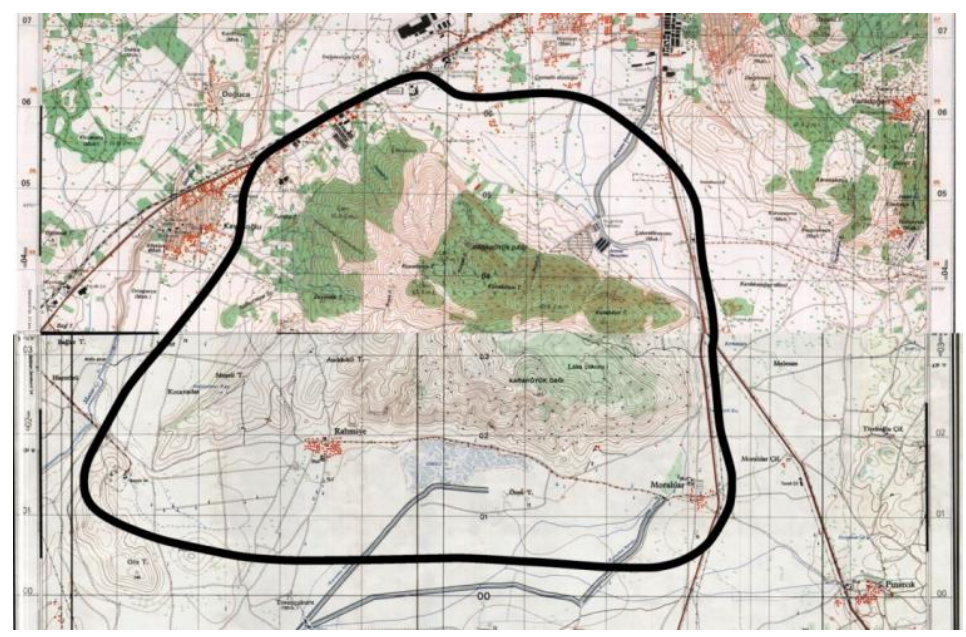

Fig. 2. Karahöyük Dağı Haritası

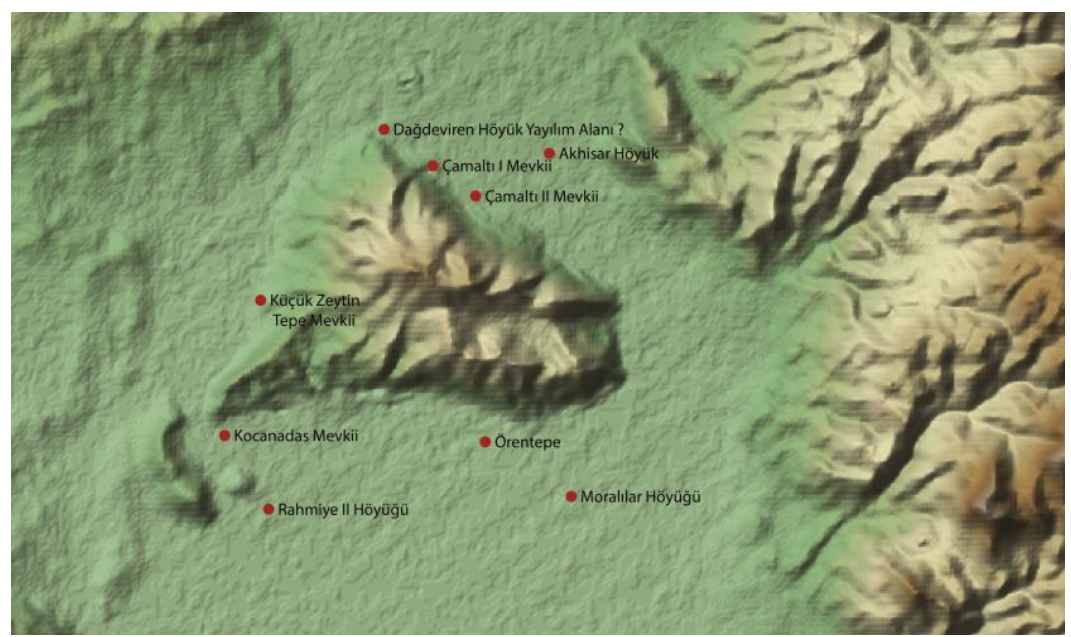

Fig. 3. Karahöyük Dağı ve Çevresinde Tespit Edilen Höyük ve Yamaç Yerleşimleri 


\section{Karahöyük Dağının Kuzeyinde Yer Alan Yerleşimler}

\section{Dağdeviren Höyüğü Yayılım Alanı? (Karahöyük Dağının Kuzeydoğusundaki Arazi) (Fig.4)}

Çamaltı Mevkiinin kuzeybatısındaki arazide 2017 yılında gerçekleştirilen yüzey araştırmaları sırasında günümüzdeki Balıkesir-Manisa yolunun ${ }^{5}$ güneybatısında kalan tarım arazisi içerisinde seramik parçaları bulunmuştur ${ }^{6}$. 38 $53^{\prime} 58^{\prime \prime}$ Kuzey, $27^{\circ} 47^{\prime} 51^{\prime \prime}$ Doğu koordinatlarında yer alan arazide yapılan incelemelerde en erken ITÇ seramiklerine rastlanılmıştır. ITÇ seramikleri dışında Roma (MS I-II. yüzyıl), Doğu Roma ve Osmanlı dönemlerine tarihleyebileceğimiz seramik parçaları da anılmaya değerdir.

Söz konusu alanın anlaşılabilmesi adına yakınında yer alan bir höyükle bağlantısını dikkate almak gereklidir. Arazinin kuzeyinde Dağdeviren Höyüğü yer almaktadır. Dağdeviren Höyüğü ilk kez D. French tarafından tespit edilmiştir. Fakat "Akırbey Çiftlik" adıyla bilim dünyasına tanıtılmıştır ${ }^{7}$. Höyüğün $90 \mathrm{~m}$ çapında ve $6 \mathrm{~m}$ yüksekliğinde olduğunu değinmektedir. E. Akdeniz ise söz konusu höyüğün adının D. French tarafından hatalı bir şekilde "Akırbey Çiftliği" olarak adlandırıldığını belirterek söz konusu höyüğün "Dağdeviren Höyük" olarak isimlendirilmesi gerektiğini ifade etmiştir ${ }^{8}$. Höyüğün $120 \times 60 \mathrm{~m}$ boyutlarında ve $12 \mathrm{~m}$ yüksekliğinde olduğunu belirtmektedir. E. Akdeniz yüzey araştırması çalışmaları sırasında araziden ITÇ, OTÇ ve STÇ seramik parçaları bulmuştur. Söz konusu erken dönem malzemesine ek olarak Hellenistik, Roma ve Doğu Roma dönemleri seramik parçaları da tespit edilmiştir ${ }^{9}$.

Günümüzde kullanıma açılan İzmir-istanbul otoyolunun Akhisar bağlantısı Dağdeviren Höyüğünün hemen güneyinde yer almaktadır. Otoyol inşası sırasında arkeolojik buluntuların tespit edilmesinin ardından Manisa Müzesi uzmanları tarafından söz konusu alanda bir kazı çalışması başlatılmışı ır ${ }^{10}$. Oldukça önemli buluntu ve kalıntıların tespit edildiği çalışmalar sırasında iTç tarihlenen mezarların bulunması oldukça önemlidir ${ }^{11}$.

Araştırma ekibimiz tarafından incelenen arazi ile Dağdeviren Höyüğü arası yaklaşık olarak 450 m civarındadır. Höyüğün güneyinde yer alan Balıkesir-Manisa yolunun ilk inşası sırasında höyüğün çevresindeki malzemenin bir miktar dağılmış olma intimali oldukça yüksektir. Bu düşünceden yola çıkarak çalışma kapsamında incelenen seramiklerin Dağdeviren Höyüğü yayılım sahası içerisinde değerlendirmek mantıklı olacaktır.

\section{Karahöyük Dağının Doğusunda Yer Alan Höyük ve Yamaç Yerleşimleri}

\section{Akhisar Höyük (Fig.5)}

Karahöyük Dağının güneyinde, eski Akhisar-Gölmarmara yolunun batısında, 3853'47" Kuzey, $27^{\circ} 49^{\prime} 40^{\prime \prime}$ Doğu koordinatlarında yer almaktadır. Söz konusu arazi günümüzde tarım alanı olarak kullanılmaktadır. Akhisar Höyük ilk kez David French tarafından tespit edilmiştir ${ }^{12}$. D. French

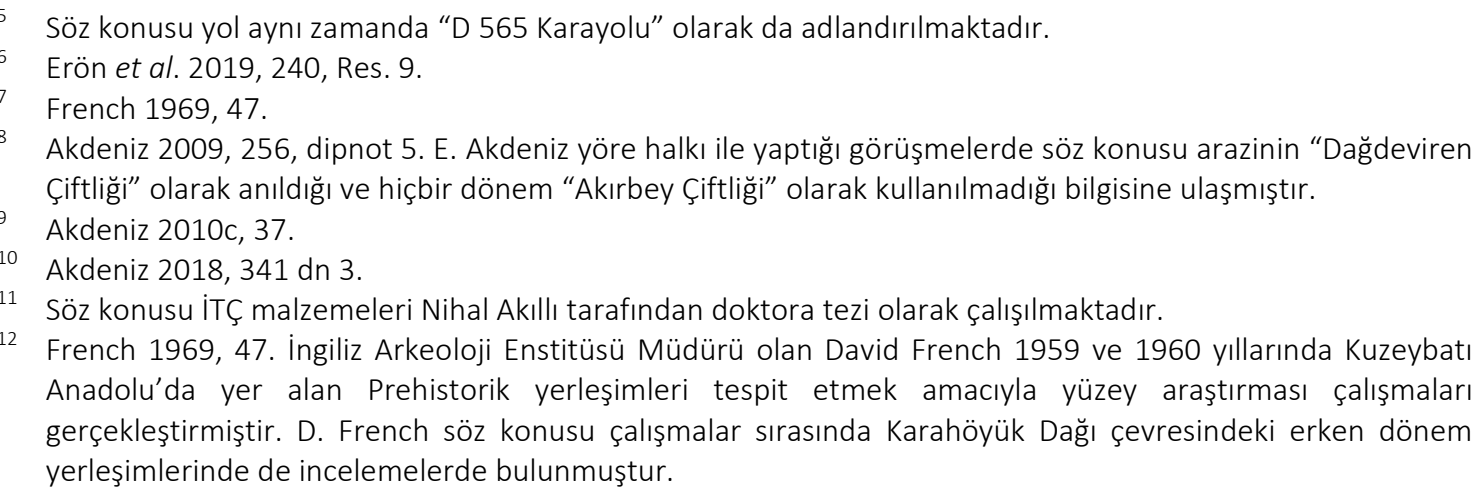


1959 yılı araştırması sırasında araziyi incelemiştir. Manisa bölgesinin erken dönem iskanı konusunda çalışmaları olan E. Akdeniz ${ }^{13}$ Akhisar Höyüğü'nü tekrar incelemiştir ${ }^{14}$. Söz konusu höyük ekibimiz tarafından 2017 araştırmaları kapsamında tekrar değerlendirilmiştir ${ }^{15}$.

Akhisar Höyüğü bölgedeki diğer höyüklerde de gördüğümüz üzere çok fazla yüksekliğe sahip değildir. Karahöyük Dağı çevresindeki höyüklerin yüksekliklerini kaybetmesinde tarımsal faaliyetlerin çok önemli bir rolü vardır. D. French Akhisar Höyüğü’nü $70 \mathrm{~m}$ çapında, 2-3 m yüksekliğinde bir alanı kapladığını ifade etmektedir ${ }^{16}$. E. Akdeniz ise höyüğün $150 \times 100 \mathrm{~m}$ boyutlarında, $3 \mathrm{~m}$ yüksekliğinde olduğunu belirtmektedir ${ }^{17}$.

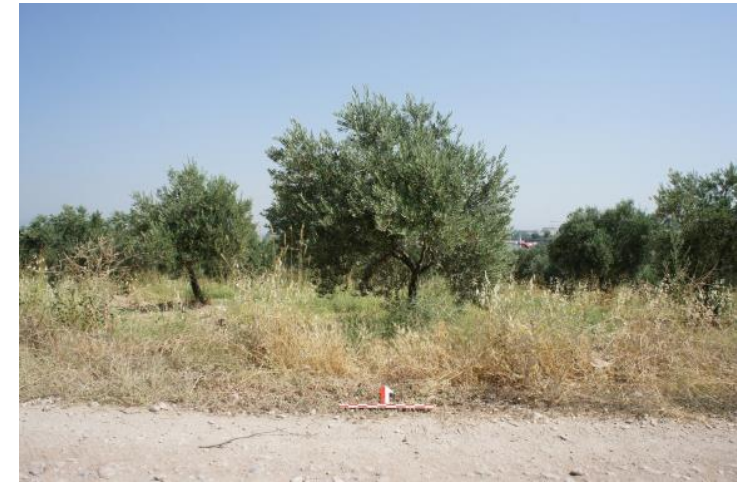

Fig. 4. Dağdeviren Höyüğü Yayılım Alanı ?

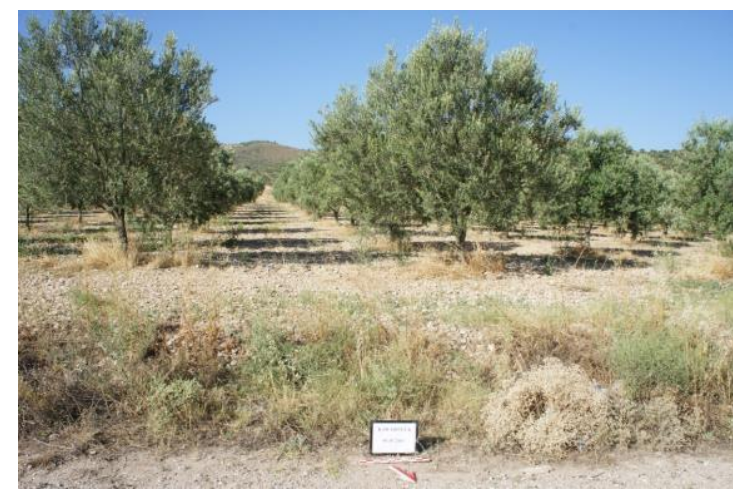

Fig. 6. Çamaltı I Mevkii

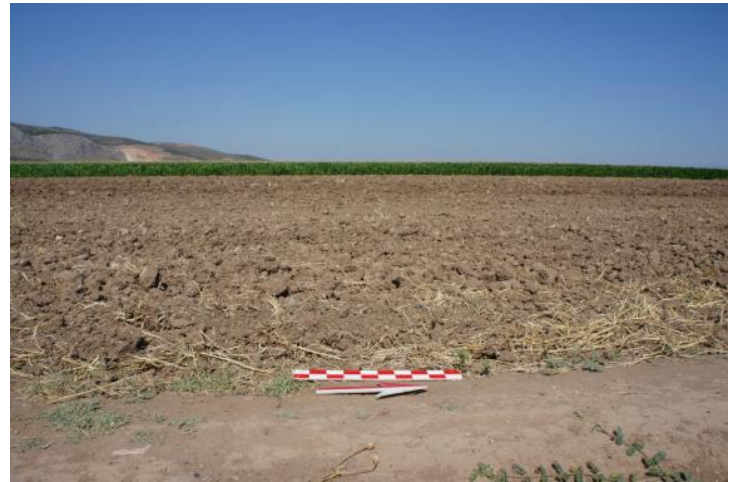

Fig. 5. Akhisar Höyük

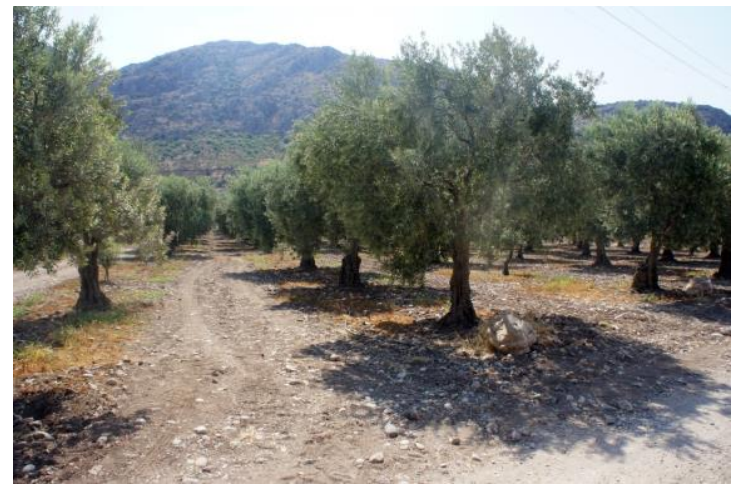

Fig. 7. Çamaltı II Mevkii

Ekimiz tarafından höyük üzerinde yapılan incelemelerde SKÇ-ITÇ, OTÇ, ODÇ ve Roma Dönemine tarihlendirebileceğimiz seramik parçaları bulunmuştur. Seramik buluntularının önemli bir bölümünü Geç Kalkolitik-illk Tunç Çağı arasına tarihlendirilen parçalar oluşturmaktadır. OTÇ seramik buluntularının sayısı ITÇ buluntularına kıyasla bir hayli azdır. Höyük yüzeyinde yaptığımız incelemeler sırasında STÇ seramik parçalarına rastlanılmamıştır. STÇ seramik örneklerindeki

13 Prof. Dr. Engin Akdeniz 2007-2009 yılları arasında Manisa ve çevresinin Prehistorik ve Protohistorik çağlardaki durumunun tespiti amacıyla bir yüzey araştırması çalışması gerçekleştirmiştir. Söz konusu yüzey araştırması çalışmasının tamamlanmasının ardından Thyateira kenti ve Hastane Höyük alanında kazı çalışmalarına başlamıştır. E. Akdeniz'in Akhisar ve çevresindeki erken dönem kültürleri konusunda yaptığı yayınlar için bkz; Akdeniz 2009, 255-266; 2010a, 154-156; 2010b, 65-83; 2011a, 10-15; 2012, 51-53; 2013, 7-9, 11-23; 2014a, 21-45; 2014b, 126-129; 2018, 340-344; Akdeniz et al. 2015, 122-127; Akdeniz-Erön 2016, 83-85; 2017, 407-408; Akdeniz et al. 2018, 7; Akdeniz et al. 2019, 674-676.

14 Akdeniz 2009, 256; 2011b, 15-16, Res. 14

15 Erön et al. 2019, 238, Res. 2-4.

16 French 1969, 47.

17 Akdeniz 2010c, 21. 
kesintinin ardından MÖ VIII-VI. yüzyıllar arasına tarihlendirebileceğimiz Lydia seramikleri tespit edilmiştir. Bölgenin kendine has yerel bir seramik kültürü olarak tanımlayabileceğimiz Demir Çağı'na tarihlendirilen Lydia seramik örneklerinin bulunması oldukça önemlidir. Höyükte yapılan incelemelerde Hellenistik Dönem'e tarihlendirilen seramik parçaları da bulunamamıştır. Buna karşılık Roma Dönemine tarihlendirebileceğimiz seramik örnekleri tespit edilmiştir. Söz konusu seramik buluntularının yanı sıra höyükte çakmaktaşı ve taş aletlerin varlığının tespit edilmesi oldukça değerlidir. Arazide yapılan incelemeler sırasında Roma Dönemi'ne tarihlendirebileceğimiz iki adet mimari parça da tespit edilmiştir ${ }^{18}$.

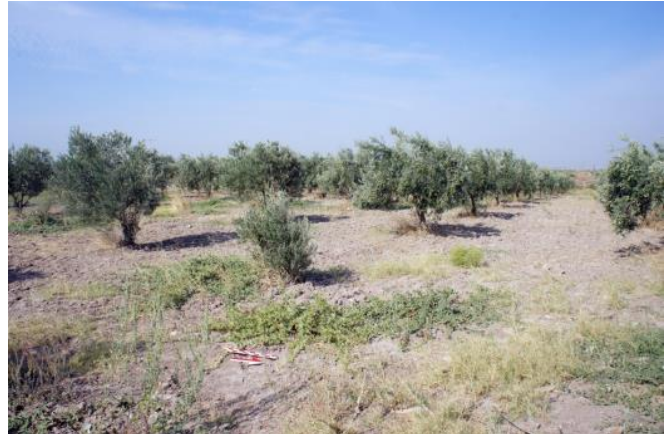

Fig. 8. Moralılar Höyüğü

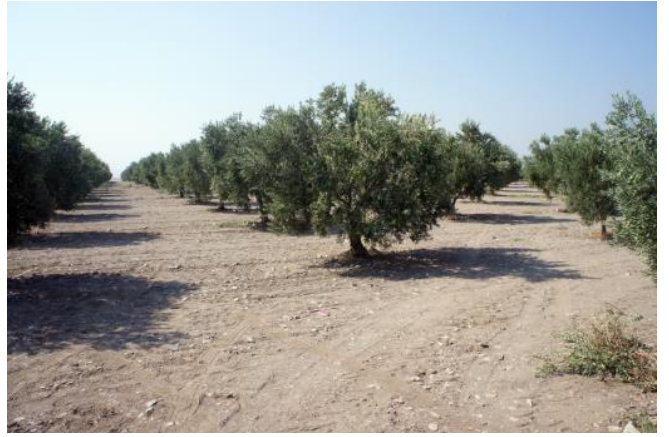

Fig. 10. Rahmiye II Höyüğü

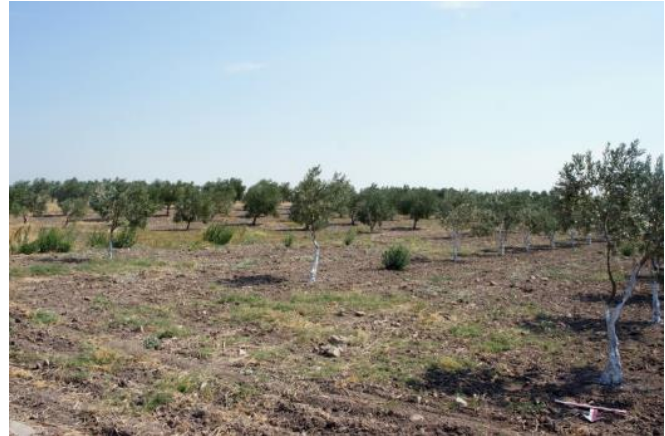

Fig. 9. Örentepe Höyüğü

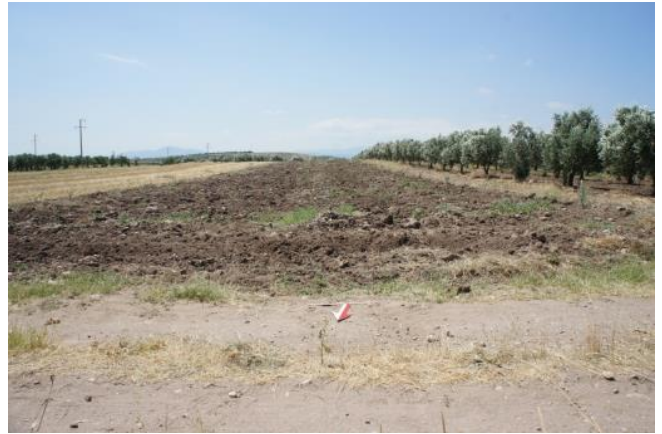

Fig. 11. Kocanadas Mevkii

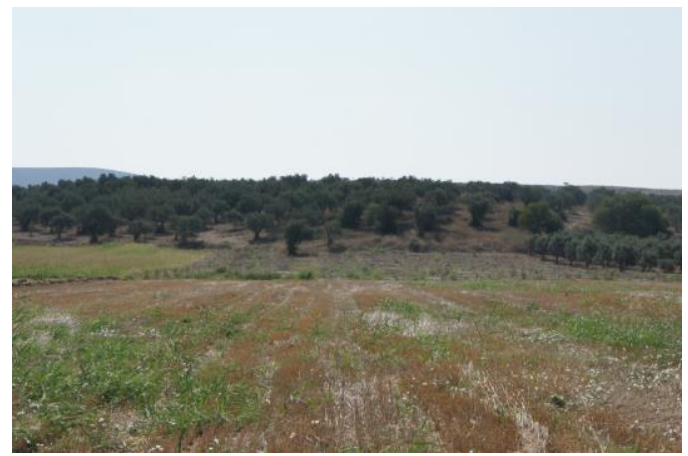

Fig. 12. Küçük Zeytin Tepe Mevkii

D. French Akhisar Höyük'te gerçekleştirdiği çalışmalar sırasında gri/siyah açkılı, kırmııı astarlı, gri seramik parçaları bulmuştur ${ }^{19}$. E. Akdeniz ise yüzey araştırması çalışmaları sırasında GNÇ, ITÇ,

18 Söz konusu parçalardan bir tanesi mermerden yapılmış bir geison-sima bloğudur. Eserin üzerinde tahrip edilmiş bir aslan başı çörtenin izleri görülebilmektedir. Aslan başı çörtenin varlığı parçanın yanal sima parçası olduğunu anlamamıza yardım olmaktadır. Eser genel iş̧̧iliği dikkate alınarak Roma Dönemi'ne tarihlendirilmiştir.

19 French 1969, 47. 
OTÇ ve STÇ dönemlerine tarihlediği seramik parçaları tespit etmiştir ${ }^{20}$. Akhisar Höyükte GNÇ seramik parçalarının bulunması oldukça önemlidir. Karahöyük Dağı ve yakın çevresinde Neolitik Çağ buluntusu veren merkezler Manisa il sınırları içerisindeki yerlerle kıyaslandığında sayıca bir hayli fazladır. Akhisar Höyük dışında araştırma sahamız içerisinde yer alan Moralılar Höyüğ̈̈ ${ }^{21}$ ve Kocanadas Mevkii'nde yer alan höyükte ${ }^{22}$ GNÇ seramik parçaları bulunmuştur. Yine araştırma sahamızın çok yakınında yer alan Kulaksızlar ${ }^{23}$ ve Hastane Höyük ${ }^{24}$ alanlarında GNÇ buluntularının varlığı bilinmektedir. Ekibimiz tarafından gerçekleştirilen çalışmalar sırasında Akhisar Höyük'te GNÇ ve STÇ dönemlerine tarihlendirilebilecek seramik parçaları ne yazık ki bulunamamıştır. Akhisar Höyüğünün günümüzde tarım faaliyetleri açısından kullanılması araştırmalar sırasında bazı dönemlere ait seramik örneklerinin bulunamayışını açıklamaktadır.

\section{Çamaltı I Mevkii (Yamaç Yerleşimi) (Fig. 6)}

Yöre halkı tarafından "Çamaltı Mevkii" olarak adlandırılan arazi Karahöyük Dağının kuzeydoğusunda yer almaktadır. 2016 ve 2017 yılı araştırmaları sırasında söz konusu alanda birbirine yakın yamaç yerleşimleri tespit edilmiştir.

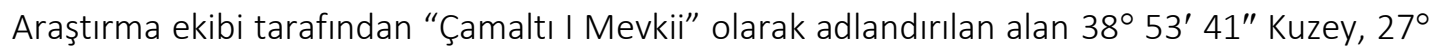
48' 24" Doğu koordinatlarında yer almaktadır. 2016 yılı araştırmaları sırasında yüzeyde ODÇ (Lydia seramiği) ve Doğu Roma-Osmanlı dönemleri seramik parçaları bulunmuştur ${ }^{25}$. Erken dönem seramik buluntu sayısı çok fazla değildir. Buna karşılık yüzeyde çok sayıda sırlı Doğu Roma ve Osmanlı dönemlerine tarihlenebilecek seramik parçalarına rastlanılmıştır.

2017 yılı çalışmaları sırasında Çamaltı I mevkiinin doğusunda $38^{\circ} 53^{\prime} 43^{\prime \prime}$ Kuzey $27^{\circ} 48^{\prime} 18^{\prime \prime}$ Doğu koordinatlarında çok sayıda seramik parçası bulunmuştur. Araştırma ekibi ilk başta söz konusu alanı yeni bir yamaç yerleşimi olarak değerlendirerek Çamaltı III mevkii olarak

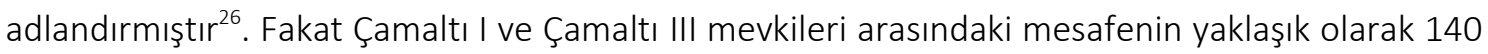
m olması aynı yer olabilecekleri düşüncesini akla getirmektedir. Söz konusu nedenle Çamaltı III mevkiinde bulunan eserlerin Çamaltı I içerisinde değerlendirilmesine karar verilmiştir. Günümüzde zeytinlik olarak kullanılan arazi üzerinde çok sayıda seramik parçası bulunmuştur. Geç antikçağ, Doğu Roma ve Osmanlı dönemlerine tarihlenen seramik örneklerinin büyük çoğunluğunu Doğu Roma ve Osmanlı seramikleri oluşturmaktadır. Seramik buluntularının yanı sıra bir adet Osmanlı Dönemi'ne tarihlenen köpek figürini tespit edilmiştir ${ }^{27}$.

Çamaltı I mevkiinde yer alan yamaç yerleşimi ilk kez ekibimiz tarafından tespit edilmiştir. Bu açıdan oldukça önemlidir. Seramik buluntuları alandaki iskanın daha çok Doğu Roma ve Osmanlı dönemlerinde yoğun olduğunu düşündürmektedir.

\section{Çamaltı II Mevkii (Yamaç Yerleşimi)(Fig. 7)}

Çamaltı II mevkii olarak adlandırılan yamaç yerleşimi 2016 yılı çalışmaları sırasında tespit

20 Akdeniz 2010c, 22; 2011a, 17; 2011b, 15; 2013, 8.

21 French 1969, 50; Dinç 1997, 266-267, Res. 19-21; Takaoğlu 2004, 743-751; Lichter 2005, 61-63, 66; Akdeniz 2009, 256; 2010c, 56-62; 2011a, 11, Fig. 5; 2011b, 20; 2013, 8, Foto 27; Erön et al. 2018, 151-152, Res. 6-7.

22 Karahöyük Dağı'nın güneydoğusunda yer alan Kocanadas Mevkii'nde 2018 yılı yüzey araştırması çalışmaları sırasında Geç Neolitik-Erken Kalkolitik Dönem'e tarihlendirilen seramik parçaları bulunmuştur.

23 Dinç 1996, 11-41; Takaoğlu 2001, 157-168; Akdeniz 2010b, 70-71, 74.

24 Akdeniz-Erön-Akıllı 2019, 675.

25 Erön et al. 2018, 149.

26 Erön et al. 2019, 239, Res. 5.

27 Erön et al. 2019, 239, Res. 7. 
edilmiştir ${ }^{28} .38^{\circ} 53^{\prime} 26^{\prime \prime}$ Kuzey, $27^{\circ} 48^{\prime} 52^{\prime \prime}$ Doğu koordinatlarında yer alan zeytinlik arazisinde yapılan incelemelerde çok sayıda kırık seramik parçası bulunmuştur. Seramik paraları yamaç yerleşiminin erken dönemlerden itibaren iskan gördüğünü düşündürmektedir. ITÇ seramikleri en erken buluntu grubunu oluşturmaktadır. Arazide STÇ'ye tarihlendirile bilinecek seramik örneklerine rastlanılmamıştır.

Çamaltı II mevkiindeki yamaç yerleşimindeki en güçlü iskanın Demir Çağı içerisinde olduğu seramik buluntularından anlaşılmaktadır. Arazide yapılan incelemeler sırasında çok sayıda Lydia seramiği parçası bulunmuştur ${ }^{29}$. Kırmızı bikrom ve damarlı boyama tekniğinde bezenmiş parçalar genel olarak ODÇ’ye (MÖ VII-VI. yüzyıl) tarihlendirilmiştir. Lydia Bölgesi konusunda çalışmaları olan C. Roosevelt söz konusu dönemi Orta Lydia Dönemi ${ }^{30}$ olarak adlandırmaktadır. Demir Çağındaki güçlü iskanın ardından yerleşim küçüldüğü seramik buluntularından anlaşımaktadır. Yerleşimde yapılan incelemeler sonucunda Hellenistik, Roma, Doğu Roma ve Osmanlı dönemlerine tarihlenen az sayıda seramik parçası bulunmuştur. Çamaltı II mevkiindeki yamaç yerleşimi de ilk kez ekibimiz tarafından tespit edilmiştir.

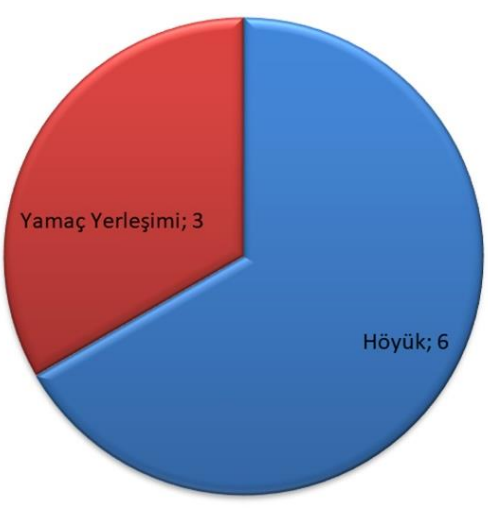

Fig. 13. Yerleşimlerin Niteliğini Gösteren Grafik

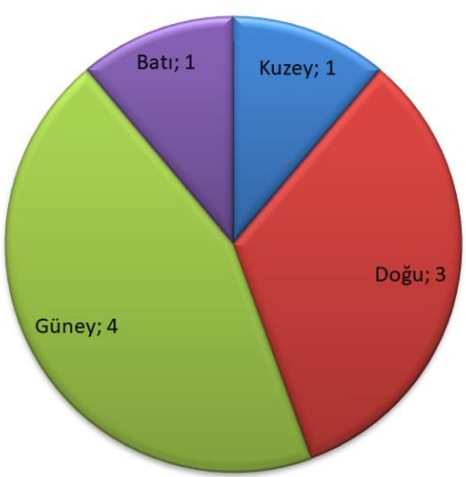

Fig. 14. Yerleşimlerin Yönlere Göre Dağılımını Gösteren Grafik

\section{Karahöyük Dağının Güneyinde Yer Alan Höyük ve Yamaç Yerleşimleri}

\section{Moralılar Höyüğü (Fig.8)}

Moralılar Höyüğü Akhisar ve çevresindeki Geç Neolitik Çağ yerleşimleri içerisinde en iyi bilinen yer olması bakımından diğer höyüklerden ayrılmaktadır. Moralılar Mahallesinin $1.3 \mathrm{~km}$ güney-

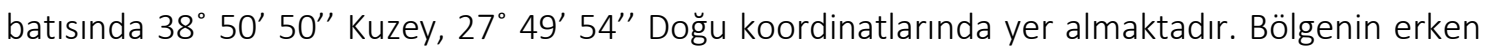
dönem iskanı konusunda çok önemli bilgilerin öğrenildiği yerleşim ilk kez D. French tarafından tespit edilmiştir ${ }^{31}$. D. French'in ardından 1990'lı yıllarda Akhisar ve çevresinde yüzey araştırması çalışmaları gerçekleştiren R. Dinç Moralılar Höyüğü’nü de incelemiştir² ${ }^{32}$. E. Akdeniz Manisa ve çevresinin erken dönem yerleşimlerini tespit etmek amacıyla gerçekleştirdiği yüzey araştırması

28 Erön et al. 2018, 150, Res. 4.

29 Çakan 2019, 355-356, Fig. 4-5.

30 Lydia Kültürünün kendisine has bir kronoloji içerisinde değerlendirilmesi gerektiğini düşünen bilim insanları bulunmaktadır. C. Roosevelt bu araştırmacılardan bir tanesidir. Roosevelt, Lydia kültürünün ortaya çıkışı ve devamındaki olayları dikkate alarak söz konusu kültürü Erken Lydia (MÖ 1200-700), Orta Lydia (MÖ 700546) ve Geç Lydia (MÖ 546-334) olarak üç başlık altında incelemiştir. Kronoloji önerisi için bkz; Roosevelt 2017, 34.

31 French 1969, 50.

32 Dinç 1997, 266-267, Res. 19-21. 
çalışmaları sırasında Moralılar Höyüğü'nde de çalışmalar yapmıştır ${ }^{33}$. Söz konusu çalışmaların ardından $2016^{34}$ ve 2018 yıllarında ekibimiz tarafından Moralılar Höyüğü tekrar incelenerek son durumu yeni buluntular ışığında bilim dünyasına tanıtılmaya çalışılmıştır. Yukarıdaki çalışmalara ek olarak bölgenin erken dönem iskanı konusunda çalışmaları olan T. Takaoğlu ${ }^{35}$ ve C. Lichter ${ }^{36}$ gibi önemli araştırmacılar da Moralılar Höyüğü ve buluntularından bahsetmişlerdir.

Moralar Höyüğü bölgedeki diğer önemli höyüklerin büyük çoğunluğunda olduğu gibi basık yayvan bir tepe görünümündedir. D. French 1959 yılındaki incelemeleri sırasında höyüğün 150 $\mathrm{m}$ çapında $3 \mathrm{~m}$ yüksekliğinde bir alanı kapladığını tespit etmiştir ${ }^{37}$. E. Akdeniz ise höyüğün $200 \times 150$ m çapında ve yer yer 3 m yüksekliğinde olduğunu ifade etmiştir ${ }^{38}$. Araştırma ekibimiz tarafından yapılan ölçümler de ise höyüğün genel olarak 200X150 m’lik bir alana yayıldığı anlaşılmıştır.

Ekibimiz tarafından Moralılar Höyük'te gerçekleştirilen yüzey araştırması çalışmaları sırasında GNÇ-EKÇ, Roma ve Doğu Roma dönemlerine tarihlendirilen seramik parçaları tespit edilmiştir ${ }^{39}$. Özellikle GNÇ-EKÇ seramik parçaları bir hayli fazladır. Geç dönem seramik buluntuları höyüğün güneybatısına doğru artış göstermektedir. R. Dinç tarafından gerçekleştirilen çalışmalarda ise Geç Neolitik Çağ, Hellenistik ve Roma dönemlerine tarihlendirilen seramik parçaları tespit edilmiştir ${ }^{40}$. E. Akdeniz ise höyükte GNÇ-EKÇ ve ITÇ tarihlendirilen seramik parçaları tespit etmiştir ${ }^{41}$.

Moralılar Höyügüu’nde 2016 yılında gerçekleştirilen yüzey araştırması çalışmaları sırasında arazide bulunan bir taş yassı balta ile Mehmet Aydın isimli vatandaştan hibe yoluyla alınan bir diğer taş yassı balta ${ }^{42}$ anılmaya değerdir. Geç Neolitik Çağ'a tarihlendirilen taş yassı baltaların benzer bir örneği E. Akdeniz tarafından gerçekleştirilen çalışmalar sırasında da bulunmuştur ${ }^{43}$.

Moralılar Höyüğü’nün gerçek yüksekliğini tespit etmek günümüzde oldukça zordur. 1955 ve 1956 yıllarında arazinin yaklaşık 4 km güneyinde inşa edilmeye başlanılan havalimanı inşaatı sırasında höyükten toprak alınmıştır ${ }^{44}$. Bu durum höyükteki dönemler arası büyük boşluğu açıklamaktadır. Ayrıca arazinin tarım faaliyetleri açısından kullanılıyor olması höyükteki tahribatı arttırmaktadır.

\section{Örentepe Höyüğü (Fig. 9)}

Örentepe Höyüğü Karahöyük Dağı́'nın güneyinde $38^{\circ} 51^{\prime} 21^{\prime \prime}$ Kuzey, $27^{\circ} 49^{\prime} 6^{\prime \prime}$ Doğu koordinatlarındadır. Araştırma ekibimiz tarafından 2016 yılında incelenmiştir ${ }^{45}$. Örentepe Höyüğü Karahöyük Dağı çevresinde isimlendirilmesi problemli olan yerleşim yerlerinden bir tanesidir. E.

33 Akdeniz 2009, 256-257. E. Akdeniz'in Moralılar Höyüğü konusundaki yayınları için bkz; Akdeniz 2001b, 20, Res. 25; 2011a, 11, Fig. 5; Akdeniz 2013, 8, Foto 27.

34 Erön et al. 151-152, Res. 6-7.

35 Takaoğlu 2004, 743-751.

36 Lichter 2005, 61-63, 66.

37 French 1969, 50.

38 Akdeniz 2009, 256; 2010c, 55.

39 Erön et al. 2018, 151, Res. 7.

40 Dinç 1997, 266-267.

41 Akdeniz 2009, 256-257; 2010c, 56-62.

42 Mehmet Aydın söz konusu baltayı Moralılar Höyüğü çevresinde bulduğunu beyan etmiştir. Bir tutanakla teslim alınan eser Manisa Müzesi'ne teslim edilmiştir.

43 Akdeniz 2010c, 62.

44 Akdeniz 2010c, 56.

45 Erön et al. 2018, 152, Res. 9. 
Akdeniz tarafından bölgede gerçekleştirilen çalışmalar sırasında Örentepe Mevkii'nde birbirine çok yakın iki adet yerleşim tespit edilmiştir. Daha kuzeyde yer alan yerleşim "Örentepe I"4" olarak isimlendirilmiş, daha güneyde yer alan yerleşim ise "Örentepe II Höyüğü "77" olarak anılmıştır. Araştırma ekibimiz tarafından alanda gerçekleştirilen çalışmalarda tek bir yerleşim tespit edilebildiği için "Örentepe Höyüğü" olarak adlandırılması uygun görülmüştür.

Örentepe Höyüğü’nün yer seçiminde hemen yanında yer aldığı düşünülen gölün önemli bir rolü olmalıdır. Insanoğlu yer seçimi yaparken su kaynaklarına yakın olmayı her zaman gözetmiştir. Günümüzdeki yerleşim yerleri içinde aynı durum geçerlidir. Karahöyük Dağı'nın güneyinde yer alan göl çevresindeki erken dönem yerleşimlerinin su ihtiyacını karşılamış olmalıdır. "Yemişli Gölü" olarak adlandırılan göl ne yazık ki, yakın zamanda kurutulmuştur.

Arazide yapılan incelemeler sırasında OTÇ'ye tarihlendirebileceğimiz seramik parçaları bulunmuştur. Erken dönem seramiklerinin yanı sıra ODÇ (Lydia seramikleri), Roma, Doğu Roma ve Osmanlı dönemleri seramiklerinin varlığı höyükteki yerleşimin sürekliliğine güzel bir kanıttır.

\section{Rahmiye II Höyüğü (Tosuntepe Mevkii) (Fig. 10)}

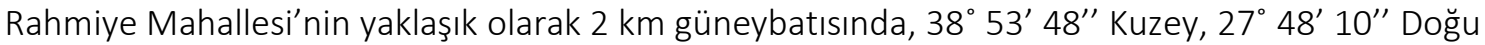
koordinatlarında yer almaktadır. Yöre halkının Tosuntepe Mevkii olarak adlandırdığı mevkide araştırma ekibimiz tarafından $2016^{48}$ ve 2018 yıllarında incelemeler yapılmıştır. Rahmiye ॥ Höyüğü ilk kez D. French tarafından gerçekleştirilen yüzey araştırması çalışmaları sırasında tespit edilmiştir $^{49}$. E. Akdeniz başkanlığındaki bir ekip tarafından 2007 yılında höyük tekrar incelenmiştir ${ }^{50}$.

Höyüğün bir tarım arazisi üzerinde yer alması kapladığı alanın tespitini gerçekten de çok zorlaştırmaktadır. D. French'in 1959 yılındaki incelemesi sırasında höyüğün 150 m çapında ve 5 $m$ yüksekliğinde bir alanı kapladığı bilinmektedir ${ }^{51}$. E. Akdeniz'in araştırmaları sırasında ise höyüğün 200×150 m çapında bir alanı kapladığı ifade edilmiştir ${ }^{52}$. Ekibimiz tarafından gerçekleştirilen ölçümlerde ise höyüğün kabaca 200×150 m çapında bir alanı kapladığı tespit edilmiştir. Fakat höyüğün yüksekliği tarım faaliyetleri nedeniyle günden güne azalmaktadır.

Araştırma ekibimiz tarafından 2016 yılında gerçekleştirilen yüzey araştırması çalışmaları sırasında ODÇ, Hellenistik ve Roma dönemlerine tarihlendirilen seramik parçaları bulunmuştur ${ }^{53}$. ODÇ'ye tarihlendirilen parçalar Lydia seramikleridir. 2018 yılı çalışmalarında ise arazide az miktarda ODÇ (Lydia seramikleri), Hellenistik, Roma, Doğu Roma ve Osmanlı dönemlerine tarihlendirilen seramik parçaları tespit edilmiştir. Höyükte erken döneme tarihlendirilen seramiklerin bulunamayışı oldukça ilginçtir. Ekibimiz tarafından gerçekleştirilen çalışmalar sırasında bulunan bir geç dönem ağırşağı anılmaya değerdir. E. Akdeniz başkanlığındaki ekip tarafından gerçekleştirilen çalışmalarda ise ITÇ ve STÇ’ye tarihlendirilen az sayıda seramik

Akdeniz 2010c, 62-63, Res. 102-103; 2011b, 21. Söz konusu alanda E. Akdeniz başkanlığında gerçekleştirilen çalışmalar sırasında OTÇ tarihlendirilen seramik buluntuları ile karşılaşılmışır.

47 Akdeniz 2010a, 154; 2010c, 63-64; 2011b, 21. E. Akdeniz Örentepe II Höyüğünde az sayıda iTÇ seramiği bulmuştur. Söz konusu erken dönem malzemesinin yanı sıra geç dönem seramikleri de tespit edilmiştir. Örentepe II Höyüğü için ayrıca bkz; Erdan 2010, 23-24.

48 Erön et al. 2018, 153, Res. 13.

49 French 1969, 50.

50 Akdeniz 2009, 257.

51 French 1969, 50.

52 Akdeniz 2009, 257; 2011b, 21.

53 Erön et al. 2018, 153. 
parçası tespit edilmiştir ${ }^{54}$.

\section{Kocanadas Mevkii (Fig. 11)}

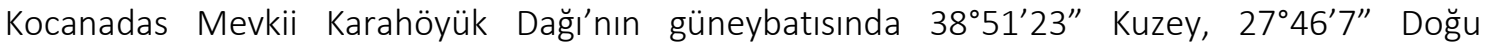
koordinatlarındadır. Kayalığlu Mahallesinin $5.3 \mathrm{~km}$ güneyinde, Rahmiye Mahallesi'nin $2 \mathrm{~km}$ batısında yer almaktadır. Söz konusu alanda 2017 yılında yapılan incelemeler sırasında daha önceki çalışmalarda değinilmeyen bir höyük yerleşiminin izlerine rastlanılmıştır ${ }^{55}$. Arazinin tarımsal faaliyetler için sürüleceği düşüncesiyle 2018 yılı çalışma programı içerisinde tekrar incelenmiştir.

Kocanadas Mevkii'nde yer alan höyük yayvan bir tepe görünümündedir. Fakat 196x172 m çapı dikkate alındığında bölgedeki diğer höyüklere kıyasla daha büyük bir alanı kapladığı anlaşılmaktadır. Arazinin tarım faaliyetleri nedeniyle sık sık sürülmesi nedeniyle gerçek ölçülerini tespit etmek oldukça zordur. Höyükte yapılan incelemeler sırasında buluntuların merkezde artış gösterdiği, arazinin eteklerinde ise azaldığı tespit edilmiştir.

Kocanadas Mevkii'nde yer alan höyükte 2017 ve 2018 yıllarında gerçekleştirilen araştırmalar sırasında çok sayıda seramik parçası tespit edilmiştir. Seramik buluntularından yola çıkarak höyüğün Geç Neolitik Çağ'dan başlayarak Osmanlı Dönemi'ne kadar iskan gördüğü anlaşılmıştır. Höyükte Geç Neolitik seramik parçalarına rastlanılması oldukça önemlidir. Manisa ve ilçelerinde geçmişte gerçekleştirilen çalışmalar sırasında toplam 11 adet Geç Neolitik Çağ buluntusu veren merkez tespit edilmiştir ${ }^{56}$. Kocanadas Mevkii buluntuları ile birlikte bu sayı 12'ye yükselmiştir. Höyükte yapılan incelemeler sırasında GNÇ-EKÇ, SKÇ, ITÇ, OTÇ, STÇ, EDÇ, ODÇ (Lydia Seramiği), Hellenistik, Roma, Doğu Roma ve Osmanlı dönemlerine tarihlendirilen seramik buluntuları saptanmıştır. ITÇ-STÇ arasındaki seramik buluntusu sayısındaki artış dikkat çekicidir. Seramik yoğunluğu EDÇ-ODÇ arasında da devam etmektedir. Daha sonraki dönemlerde seramik sayısında bir azalma tespit edilmiştir.

Kocanadas Mevkii'nde yer alan höyükte yapılan incelemeler sırasında 2017 yılında taştan yapılmış bir idol bulunmuştur ${ }^{57}$. "Troia Tipi İdol” grubuna ait olduğunu düşündüğümüz eser genel özellikleri dikkate alınarak iTÇ II'ye tarihlendirilmiştir. Söz konusu idolün yanı sıra 2018 yılı çalışmaları sırasında pişmiş topraktan yapılmış bir idol daha bulunmuştur. Höyüğün iTÇ içerisinde inanışları konusunda bilgi veren bu eserler oldukça önemlidir. Kocanadas Mevkii'nde yer alan yerleşimde bulunan öğütme taşları höyük ve çevresinde tarımsal faaliyetlerin yapıldığının kanıtı olarak karşımıza çıkmaktadır. Söz konusu öğütme taşlarının yanı sıra çakmaktaşı, çakmaktaşı alet ve perdah taşı buluntuları anılmaya değerdir. Arazide yapılan incelemeler sırasında bir araya toplanmış vaziyette profilli mimari yapı parçalarına da rastlanıımıştır. Mimari parçalar Roma Dönemine tarihlendirilmiştir.

\section{Karahöyük Dağı'nın Batısında Yer Alan Yamaç Yerleşimleri}

\section{Küçük Zeytin Tepe Mevkii (Fig. 12)}

Karahöyük Dağı'nın batısında 38 52"31' Kuzey, 2746"30' Doğu koordinatlarında yer almaktadır. 2018 yılı çalışmaları sırasında tespit edilmiştir. Kocanadas Mevkii ile Kayalıoğıu Mahallesi arasındaki yer yer stabilize yolun doğusunda yer almaktadır. Yapılan incelemeler sonucunda ilk kez

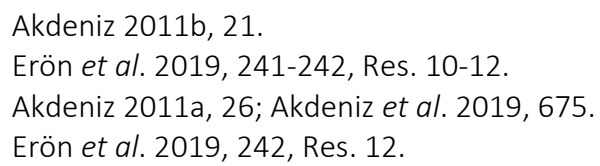


tespit edilen bir yerleşim olduğu anlaşımıştır.

Küçük Zeytin Tepe Karahöyüjk Dağı çevresindeki yamaç yerleşimlerine güzel bir örnektir. Arazide az miktarda OTÇ ve ODÇ (Lydia seramiği) seramik parçası tespit edilmiştir. Doğu Roma ve Osmanlı dönemlerine tarihlendirebileceğimiz çok sayıda sırlı seramik parçası bulunmuştur.

\section{Değerlendirme ve Sonuç}

Karahöyük Dağı ve çevresinde 2016-2018 yılları arasında gerçekleştirilen yüzey araştırması çalışmaları sırasında toplam 9 adet höyük ve yamaç yerleşimi tespit edilmiştir. Yapılan incelemeler sonucunda beş tanesinin (Akhisar Höyük, Dağdeviren Höyüğü, Moralılar Höyüğü, Örentepe Höyüğü ve Rahmiye ॥ Höyüğü) bölgede geçmiş yıllarda araştırmalar gerçekleştirilen bilim insanları tarafından tespit edilen yerleşimler olduğu anlaşımıştır. Çamaltı I, Çamaltı II, Kocanadas ve Küçük Zeytin Tepe mevkilerinde yer alan höyük ve yamaç yerleşimleri ise ilk kez ekibimiz tarafından bulunmuştur.

HÖYÜK VE YAMAC YERLEȘIMLERİ ARASI MESAFELER (KUŞ UÇUȘU)

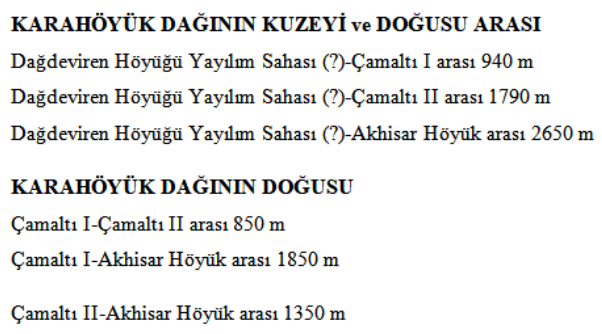

Rahmiye II Höyüğü-Kocanadas Mevkii arası $1360 \mathrm{~m}$

KARAHÖYÜK DAĞININ GÜNEYİ ve BATISI ARASI

Kocanadas Mevkii-Küçük Zeytin Tepe Mevkii aras $2190 \mathrm{~m}$

Fig. 15. Yerleşimler Arası Mesafeleri Gösteren Tablo

Araştırma sahası içerisinde kalan yerleşimlerin altı tanesi höyük (Akhisar, Dağdeviren, Moralılar, Örentepe, Rahmiye II, Kocanadas Mevkii) niteliğindedir. Çamaltı I, Çamaltı II ve Küçük Zeytin Tepe mevkilerinde yer alanların ise yamaç yerleşimi oldukları anlaşılmıştır (Fig. 13). Yapılan değerlendirmeler sonucunda Karahöyük Dağı'nın en çok güney bölümünün iskan için tercih edildiği anlaşılmıştır (Fig. 14). Moralılar, Örentepe, Rahmiye II ve Kocanadas höyükleri dağın güneyinde yer almaktadır. Günümüzde Akhisar ve çevresinin kuzeyden esen sert kuzey rüzgarlarından etkilendiği bilinmektedir. Bu durum erken yerleşimler içinde önemli olmalıdır. Karahöyük Dağının kuzey rüzgarlarından korunmak için tercih edildiği düşünülmektedir. Ayrıca geçmiş yıllarda bölgede araştırmalar gerçekleştiren bilim insanları dağın güneyinde bir gölün varlığını tespit etmişlerdir. Günümüzde kurutulan bu su kaynağının höyük yerleşimleri için de çok önemli olduğu kesindir. Akhisar Höyüğü, Çamaltı I ve Çamaltı I yerleşimleri ise dağın doğusunda yer almaktadır. Dağın kuzey ve batı bölümlerinin iskan için çok tercih edilmediği anlaşılmaktadır. Araştırmalar sırasında dağın kuzeyinde Dağdeviren Höyüğü ve batısında ise Küçük Zeytin Tepe yamaç yerleşiminin bulunduğu tespit edilmiştir.

Erken dönem iskanlarının yer seçiminde yanında yer alan yerleşimlerle olan mesafelerine dikkat edilmiş olmalıdır. Bu düşünceyle araştırma sahası içerisinde kalan höyük ve yamaç yerleşimlerinin birbirleri ile olan uzaklıkları ölçülmüştür (Fig. 15). Yapılan incelemeler sonucunda birbirlerine en yakın komşu iki yerleşimin 850 m mesafeyle Çamaltı I ve Çamaltı II olduğu tespit edilmiştir. 


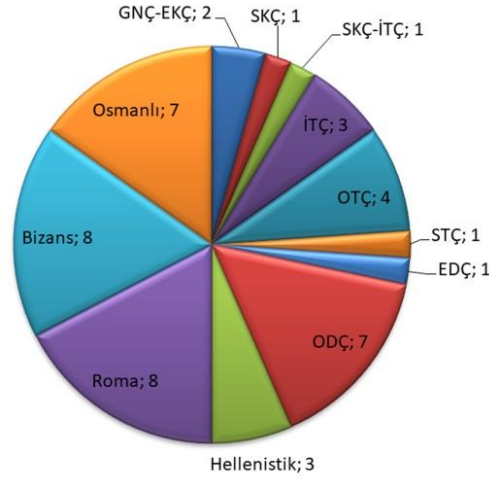

Fig. 17. Seramik Buluntularının Dönemlere Göre Görüldükleri Höyük ve Yamaç Yerleşimi Sayısını Gösteren Grafik

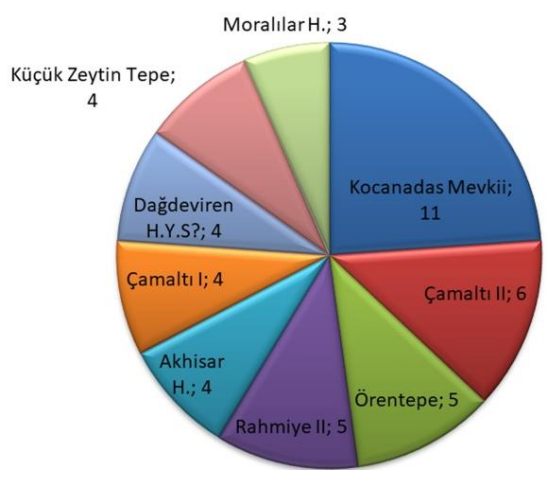

Fig. 18. Höyük ve Yamaç Yerleşimlerinde Seramik Buluntularının Görüldükleri Dönem Sayısını Gösteren Grafik

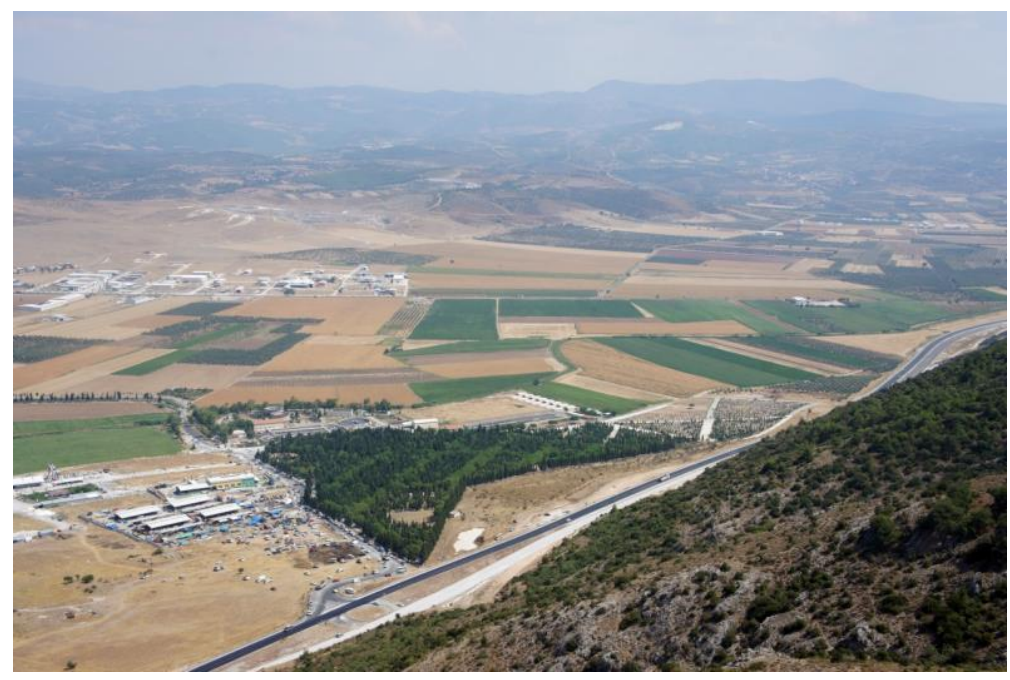

Fig. 19. Akhisar Ovası'nın Karahöyük Dağı'ndan Görünüşü

En uzak mesafe ise 5550 m ile Akhisar Höyük ile Moralılar Höyüğü arasında ölçülmüştür. Söz konusu ölçümler kuş uçuşu mesafelerdir. Günümüz köy yerleşimlerinin seçiminde de su, korunaklı alan gibi etkenlerin yanı sıra mesafelerin dikkate alındığı düşünülmektedir. Bu duruma Karahöyük Dağı çevresinden bir örnek vermemiz gerekirse Moralılar-Rahmiye mahalleleri arasındaki mesafe kuş uçuşu 4500 m olarak ölçülmüştür. Yapılan değerlendirmeler sonucunda günümüzdeki Balıkesir-Manisa yolunun aksine ulaşımın erken dönemlerde Karahöyük Dağı'nın güneyinden geçtiği düşüncesi üzerinde durulmaktadır. Geç Neolitik Çağ’dan başlayarak iskan görmeye başlayan höyük ve yamaç yerleşimleri bu basit yolun yakınlarına konumlanmış olmalıdır.

Höyük ve yamaç yerleşimlerinin iskan gördükleri dönemlerin tespitinde seramik buluntuları oldukça önemli bir rol oynamıştır (Fig. 16). Yapılan incelemeler sonucunda Moralılar Höyüğü ve Kocanadas Mevkii'nde yer alan höyükte bulunan Geç Neolitik-Erken Kalkolitik Çağ'a tarihlendirilen seramik parçaları en erken buluntu grubunu oluşturmaktadır. Bu durum Karahöyük Dağı çevresinde GNÇ'de iskanın başladığını kanıtlamaktadır. Akhisar Höyük'te geçmiş yıllarda araştırmalar yapan bilim insanları GNÇ seramik parçaları tespit etmişlerdir. Fakat ekibimiz söz konusu parçaları bulamamıştır. Bu durum arazinin sürekli tarım faaliyetler için kullanılması ile bağlantılı olarak düşünülmelidir. 
Seramik buluntuları ışı̆̆ında höyük ve yamaç yerleşimlerinin birçoğunda iskanların ODÇ, Roma, Doğu Roma ve Osmanlı dönemlerinde devam ettiği tespit ettiği anlaşılmıştır (Fig. 17). Yüzey araştırması çalışması sırasında tespit edilen 9 yerleşimin sekizinde Roma ve Doğu Roma, yedisinde ODÇ ve Osmanlı seramik parçalarına rastlanılmıştır. Dönemsel olarak incelendiğinde höyük ve yamaç yerleşimlerinde GDÇ olarak tanımlayabileceğimiz MÖ V-IV. yüzyıl arasına tarihlendirilen herhangi seramik parçası tespit edilememiştir. Bu durum Pers egemenliğinin baskıcı tutumu ile bağlantılı olmalıdır. STÇ’ye tarihlendirilen seramik parçaları sadece Kocanadas Mevkii'nde yer alan höyükte bulunmuştur.

Höyük ve yamaç yerleşimlerinde iskanın sürekliliği seramik buluntuları yardımıyla anlaşılmaya çalışılmıştır (Fig. 18). Yapılan incelemeler sonuncunda Kocanadas Mevkii'nde yer alan höyüğün GDÇ hariç bütün dönemlerde iskan gördüğü seramik buluntuları yardımıyla tespit edilmiştir. Moralılar Höyüğü ise en az farklı dönem tespit edilen yerleşim yeridir. Söz konusu alanda üç farklı dönemi işaret eden seramik buluntuları saptanmıştır. Höyükte yapılan incelemelerde GNÇ-EKÇ, Roma ve Doğu Roma dönemlerine tarihlendirilen seramik parçaları bulunmuştur. Dönemsel boşluklar Moralılar Höyügü̈nün bulunduğu alandan havaalanı inşaatı için toprak alınması ile bağlantıı olmalıdır.

Bereketli Akhisar Ovası'nın Geç Neolitik Çağ'dan başlayarak iskan için tercih edilen bir coğrafya olduğu bilinmektedir (Fig. 19). Bölgede gerçekleştirilen yüzey araştırmaları sırasında tespit edilen yerleşim yeri sayısının fazlalığı bu durumu kanıtlamaktadır. 2016-2018 yılları arasında Karahöyük Dağı ve çevresinde gerçekleştirdiğimiz yüzey araştırmalarında saptanılan yeni höyük ve yamaç yerleşimleri ile birlikte bu sayı daha da artmıştır. Söz konusu alanda kazı çalışmalarının da başlaması bu açıdan oldukça önemlidir. 


\section{BIBBLIYOGRAFYA}

Akdeniz 2009

Akdeniz 2010a

Akdeniz 2010b

Akdeniz 2010c

Akdeniz 2011a

Akdeniz 2011b

Akdeniz 2012

Akdeniz 2013

Akdeniz 2014a

Akdeniz 2014b

Akdeniz 2018

Akdeniz et al. 2015

Akdeniz-Erön 2016

Akdeniz-Erön 2017

Akdeniz et al. 2018

Akdeniz et al. 2019

AnSt

AST

Çakan 2019

Dinç 1996

Dinç 1997

Erdan 2010

Erön et al. 2018

Erön et al. 2019

French 1969

KST

Lichter 2005
E. Akdeniz, "2007 Yılında Manisa illi ve İlçelerinde Yürütülen PrehistorikProtohistorik Yüzey Araştırmaları". AST XXVI/2 (2009) 255-266.

E. Akdeniz, "2008 Yılında Manisa İli ve İlçelerinde Yürütülen PrehistorikProtohistorik Yüzey Araştırmaları". AST XXVII/1 (2010a) 153-174.

E. Akdeniz, "Kulaksızlar Atölyesinde Kilya Tipi Figürin Üretimi". OLBA XVIII (2010) 65-83.

E. Akdeniz, Prehistorik-Protohistorik Çağlarda Manisa ve Çevresi, TÜBITAK Projesi Sosyal ve Beşeri Bilimler Araştırma Grubu Başkanlığı, Basılmamış 107K030 No.lu Projenin Sonuç Raporu (SOBAG). Aydın 2010.

E. Akdeniz, "Neolitik Çağ’da Manisa Yöresi”. OLBA XIX (2011) 1-46.

E. Akdeniz, Tarih Öncesinden IIlk Demir Çağı'na Manisa. Akhisar 2011.

E. Akdeniz, "2010 Yılında Manisa illi ve İlçelerinde Yürütülen PrehistorikProtohistorik Yüzey Araştırmaları". AST XXIX/1 (2012) 51-68.

E. Akdeniz, "Manisa Yöresindeki Prehistorik-Protohistorik Buluntu Merkezlerinin Dönemsel ve Coğrafi Dağılımları". Akdeniz Sanat Dergisi III/6 (2013) 1-26.

E. Akdeniz, “Kuzey Lydia'daki Thyateira'nın Erken Dönem Yerleşimi:Hastane Höyüğü Kazısı". TÜBA-AR 15 (2014) 21-45.

E. Akdeniz, "2012 Yılında Thyateira Antik Kenti ve Hastane Höyüğünde Gerçekleştirilen Arkeolojik Çalışmalar". KST XXXV/2 (2014) 124-139.

E. Akdeniz, "illk Tunç Çağı'nda Manisa Yöresi'nde Yerleşim Dokusu". Adnan Menderes Üniversitesi, Sosyal Bilimler Enstitüsü Dergisi V/1 (2018) 336- 359.

E. Akdeniz, M. K. Şahin, A. Erön, "2013 Yılı Akhisar-Thyateira Antik Kenti ve Hastane Höyüğü Kazısı”. KST XXXVI/2 (2015) 121-138.

E. Akdeniz, A. Erön, "2014 Yılı Akhisar-Thyateira Antik Kenti ve Hastane Höyüğü Kazısı". KST XXXVII/2 (2016) 81-94.

E. Akdeniz, A. Erön, "2015 Yılı Akhisar-Thyateira Antik Kenti ve Hastane Höyüğü KazIsI". KST XXXVIII/2 (2017) 403-416.

E. Akdeniz, A. Erön, Y. S. Kaya, "2016 Yılı Akhisar-Thyateira Antik Kenti ve Hastane Höyüğü Kazısı". KST XXXIX/2 (2018) 1-14.

E. Akdeniz, A. Erön, N. Akıllı, "2017 Yılı Thyateira ve Hastane Höyüğü Kazıları". KST XL/1 (2019) 671-682.

Anatolian Studies.

Araştırma Sonuçları Toplantısı.

M. S. Çakan, "Akhisar, Karahöyük Dağı Yüzey Araştırması Kapsamında Incelenen Çamaltı II Mevkii ve Lydia Seramikleri". Eds. A. Erön, E. Erdan, Doğu'dan Batıya 70. Yaşında Serap Yaylalı'ya Sunulan Yazılar. Ankara (2019) 351-360.

R. Dinç, "1994 Yılı Akhisar-Kulaksızlar Mermer İdol Atölyesi Yüzey Araştırması”. AST XIII/2 (1996) 11-41.

R. Dinç, "Kulaksızlar Mermer İdol Atölyesi ve Çevre Araştırmaları". AST XIV/2 (1997) 255-282.

E. Erdan, Kum Çayı Vadisi ve Yakın Çevresinde IIlk Tunç Çağı Yerleşim Dokusu. Yayınlanmamış Yüksek Lisans Tezi, Adnan Menderes Üniversitesi. Aydın 2010.

A. Erön, E. Akdeniz, M. Çekilmez, M. S. Çakan, "2016 Yılı Karahöyük Dağı Arkeolojik Yüzey Araştırması Çalışmaları". AST XXXV/1 (2018) 147-161.

A. Erön, E. Akdeniz, M. Çekilmez, M. S. Çakan, E. Maden, S. Kızıl, "2017 Yılı Akhisar Karahöyük Dağı Yüzey Araştırması Çalışmaları". AST XXXVI/1 (2019) 237-248.

D. H. French, "Prehistoric Sites in Northwest Anatolia II. The Balıkesır and Akhisar/Manisa Areas". AnSt 19 (1969) 41-98.

Kazı Sonuçları Toplantısı.

C. Lichter, "Western Anatolia in the Late Neolithic and Early Chalcolithic: the actual state of research". Eds. C. Lichter, Byzas 2. İstanbul (2005) 59-74. 
Roosevelt 2017

Takaoğlu 2001

Takaoğlu 2004
C. H. Roosevelt, Gyges'ten Büyük Iskender'e Lydia Arkeolojisi. İstanbul 2017. T. Takaoğlu, "1999 Yılı Kulaksızlar Mermer Atölyesi Araştırması". 18. AST 2 (2001) 157-168.

T. Takaoğlu, "Moralı: A Neolithic Mound in Central Western Anatolia". Eds. T. Korkut, H. İşkan, G. Işın, Anadolu'da Doğdu-60. Yaşında Fahri Işık'a Armağan. İstanbul (2004) 743-751. 